[Agr. Biol., Chem., Vol. 31, No. 1, p. 77 84, 1967]

\title{
The Nutritional Value of D-Amino Acid in the Chick Nutrition
}

\author{
By Michihiro Sugahara, ${ }^{*}$ Takao Mormoto, ${ }^{*}$ Takaaki Kobayashi* \\ and Shujiro ARIYoshi*,** \\ *Research Laboratory of Amino Feed Industry Co., Ltd., ${ }^{* *}$ Ceneral Research \\ Laboratories of Ajinomoto Co., Inc., Yokohama, Japan \\ Received August 8, 1966
}

\begin{abstract}
The nutritional values of $16 \mathrm{D}$-amino acids in chick growth were studied on the purified diets containing crystalline amino acids as a sole source of nitrogen. Growth rate, feed consumption and nitrogen retention were measured. The nutritional values of $D$-amino acids were studied by comparing individually with the control groups fed on the diet containing all L-amino acids and negative control groups fed with the diet omitted the corresponding L-isomer. The following results were obtained. Essential amino acids: 1. Equal or almost equal nutritional value to the corresponding L-isomer; methionine, phenylalanine, leucine, proline. 2. Half nutritional value compared with L-isomer; valine. 3. Small nutritional value compared with L-isomer; tryptophan, isoleucine, histidine. 4. No nutritional value; lysine, threonine, arginine. Non-essential amino acid: 1. Equal or almost equal nutritional value to the corresponding $\mathrm{L}$-isomer; serine, tyrosine, cystine. 2 . There is a possibility that it has a slight growth retardation effect; alanine. 3. The growth retardation effect was found; aspartic acid.
\end{abstract}

The precise estimations of the nutritional values of $\mathrm{D}$-amino acids are necessary in the study of the amino acids nutrition on the crystalline amino acid diet. Some experiments have been conducted for this reason on $\mathrm{D}$ amino acids, but the results have merely limited value. A few experiments to estimate the nutritional value of $\mathrm{D}$-amino acid in chick growth were performed, even though the main practical application was directed to the poultry feed. The nutritional value of $\mathrm{D}$-amino acid has not been compared under uniform experimental condition with all members of amino acid. The chick growth studies using amino acids mixture always contained racemic amino acids in some extent and control diet containing only L-amino acids has not been used.

1) B. F. Gerulat and C. P. Berg, Arch. Biochem. Biophys., 88, 273 (1960).

2) S. H. Kamath and C. P. Berg, J. Nutrition, 82, 237 (1964).

3) S. H. Kamath and C. P. Berg, ibid., 82, 243 (1964).
As the antagonism among D-amino acids was reported, ${ }^{I \sim 5)}$ those types of experimental diet are not satisfactory. Few experiments estimating the nutritional values of $\mathrm{D}$-isomers of the non-essential amino acids have been reported.

The present study was aimed to clarify the nutritional values of D-amino acids in the chick growth.

\section{EXPERIMENTAL}

All D-amino acids used, except D-cystine,* were prepared from the racemic forms by the chemical or the enzymatic resolution. (Table I).

A day-old male chicks of White Leghorn were fed on a practical chick starter for a pretest period of 7 days. On the seventh day at 9.00 a.m. chicks were

4) L. E. Marrett and M. L. Sunde, Poultry Sci., 44, 957 (1965).

5) D. C. Snetsinger, D. G. Britzman, R. C. Fitzsimmons and P. E. Waibel, ibid., 43, 675 (1964).

* It was purchased from Mann research laboratories, Inc. New York. 
TABLe I. RESOlution Method, SPECIFIC ROTATION AND Nitrogen Content of D-Amino ACIDS PREPARED

\begin{tabular}{|c|c|c|c|c|c|c|}
\hline \multirow[b]{2}{*}{ Amino acid } & \multirow[b]{2}{*}{ Derivative } & \multirow[b]{2}{*}{ Resolution method } & \multicolumn{3}{|r|}{ Solute (g) } & \multirow[b]{2}{*}{ Nitrogen content } \\
\hline & & & {$[\alpha]_{D}^{20} S$} & Solvent used & $100 \mathrm{ml}$ Soluiion & \\
\hline Alanine & Acetyl & Acylase & -14.3 & IN-HCL & 5.8 & $15.30 \%$ \\
\hline Tyrosine & $"$ & $"$ & +11.3 & $"$ & 4.8 & 7.26 \\
\hline Methionine & $" 1$ & $"$ & -22.6 & $6 \mathrm{~N}-\mathrm{HCL}$ & 8.0 & 9.28 \\
\hline Phenylalanihe & $"$ & $"$ & +31.0 & $\mathrm{H}_{2} \mathrm{O}$ & 2.0 & 8.26 \\
\hline Leucine & $"$ & $"$ & -14.7 & $6 \mathrm{~N}-\mathrm{HCL}$ & 4.0 & 10.63 \\
\hline Arginine-HCL & $"$ & $" \prime$ & -22.4 & $"$ & 8.0 & 26.58 \\
\hline Histidine & $"$ & $"$ & +12.6 & $\mathrm{H}_{2} \mathrm{O}$ & 1.0 & 26.94 \\
\hline Alloisoleucin & " & $"$ & -36.3 & $6 \mathrm{~N}-\mathrm{HCL}$ & 4.0 & 10.12 \\
\hline Lysine-HCL & $"$ & D-Glutamic acid & -19.0 & $"$ & 7.7 & 15.22 \\
\hline $\begin{array}{l}\text { Tryptophan } \\
\text { Threonine }\end{array}$ & Acetyl-ammonium & Inoculation & -31.3 & $\mathrm{H}_{2} \mathrm{O}$ & 2.0 & 13.75 \\
\hline $\begin{array}{l}\text { Threonine } \\
\text { Valine }\end{array}$ & & $"$ & $\begin{array}{l}+28.2 \\
-27.7\end{array}$ & $\mathrm{H}_{2} \mathrm{O}$ & 6.0 & 11.58 \\
\hline Scrine & $p$-Nitrobenzoyl & Ouinine & $\begin{array}{l}-27.7 \\
-145\end{array}$ & $6 \mathrm{~N}-\mathrm{HCL}$ & 8.0 & 11.46 \\
\hline Aspartic acid & Benzoyl & Brucin & $\begin{array}{l}-14.5 \\
-24.9\end{array}$ & $1 \mathrm{~N}-\mathrm{HCL}$ & 10.0 & 13.42 \\
\hline Proline & $m$-Nitrobenzoyl & Cinchonine & $\begin{array}{l}-84.8 \\
+84.8\end{array}$ & $\mathrm{H}_{2} \mathrm{O}$ & $\begin{array}{l}8.0 \\
1.0\end{array}$ & $\begin{array}{l}10.58 \\
12.33\end{array}$ \\
\hline
\end{tabular}

TABLE II. COMPosition OF THE Control DIET

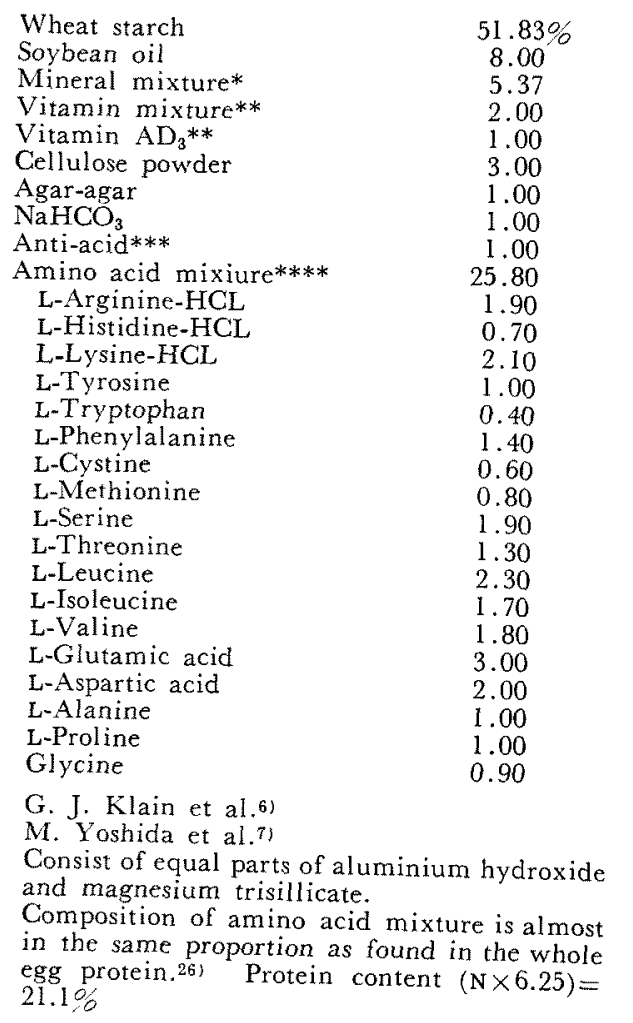

6) G. J. Klain, H. M. Scott and B. C. Johnson, Poultry Sci., 39, 39 (1960).

7) M. Yoshida, H. Hoshii and H. Morimoto, $J$. Agr. Chem. Soc. Japan, 37, 187 (1963) off from the diet and weighed. Experimental birds ( 8 birds per one section) were carefully selected for uniformity of weight. They were housed in the electrically heated brooders equipped with the wire floors. At $4.00 \mathrm{p}$.m. they were given the experimental diets. In order to have chicks eat immediately after the amino acid diets were given, it was necessary to scatter the very small quantity of the practical diet over the surface of the amino acid diets at first picking. Some birds did not start to eat, therefore forced feeding was employed for them. Chicks showed good appetite after they begun to eat. Feed and water were given ad libitum. Excreta were collected in the polyvinyl plastic dishes containing $3 \%(\mathrm{~W} / \mathrm{V})$ boric acid solution. Chicks were weighed individually at the first, fourth and seventh day. After the last weighing of chicks, the diets in the feed-boxes and on the boards bearing the excreta collecting dishes were weighed. The precipitated diets in the water-cups were dried and weighed. Feed consumption was calculated by deducting the summed amount of these wasted diets from the total diets supplied. Collected excreta were dried in the ventilated dryer at $60^{\circ} \mathrm{C}$ and were ground. Total nitrogen of excreta was measured by Kjeldahl method.

The composition of the control diet was shown in Table II. In order to remove L-amino acid to prepare negative control diet, the L-amino acid was omitted from the control diet and L-glutamic acid was added as a substitute on the nitrogen base to compensate the nitrogen content of the diet. For L-glutamic acid omission, L-aspartic acid was used as a substitute. When the total amount of amino acids in the diet was changed for the correction of nitrogen content, 
Table III. Feed Consumption, Growth Rate, Feed Utilization, Nitrogen Retention, Nitrogen Efficiency* and Protein Efficiency Ratio on L-Amino acid Lacking Diet, the Corresponding D-Amino Acid Contajning Diet and the Control Diet

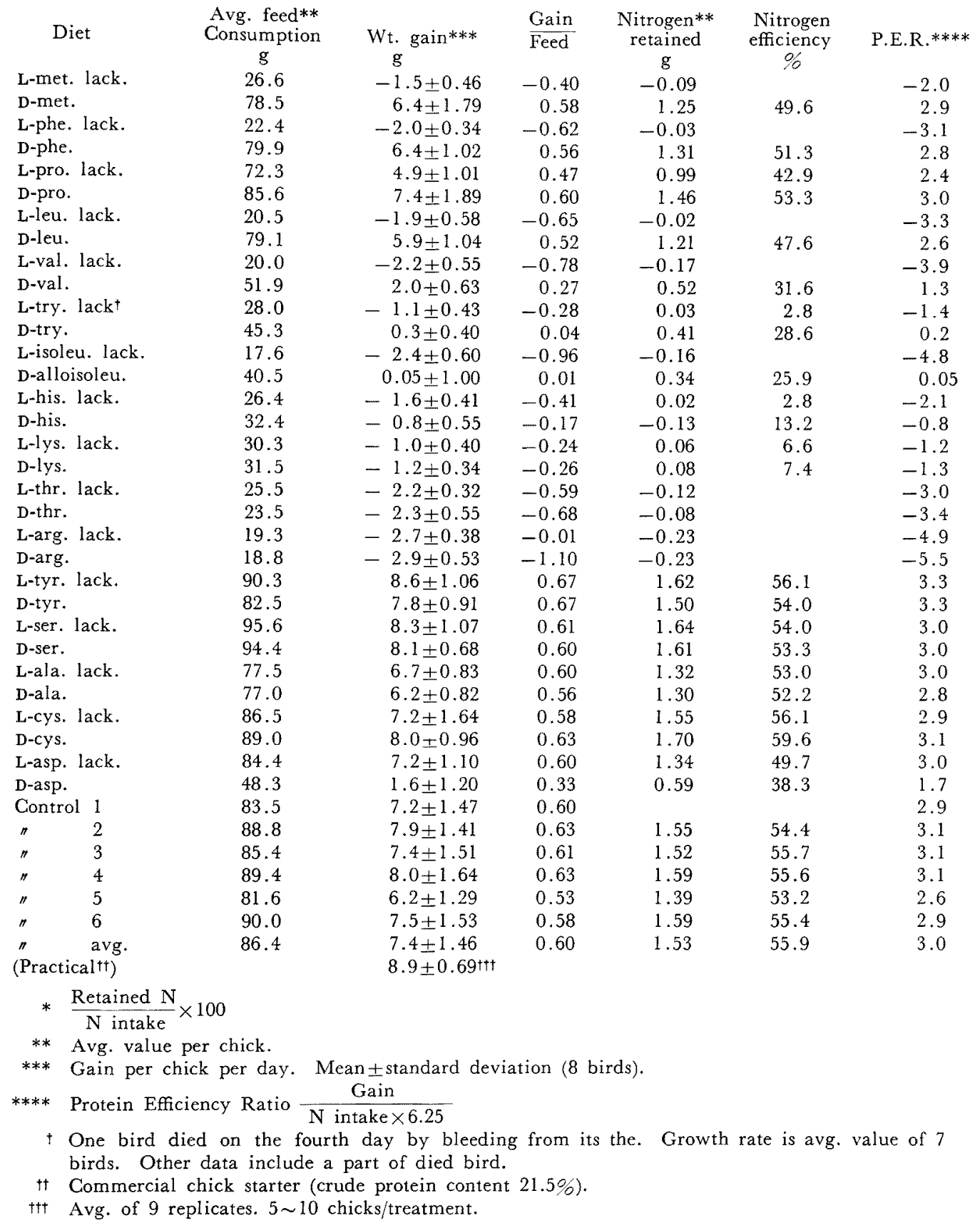


the content of wheat starch was regulated. For estimation of the nutritional value of $\mathrm{D}$-amino acid, L-amino acid was replaced by the corresponding D-amino acid.

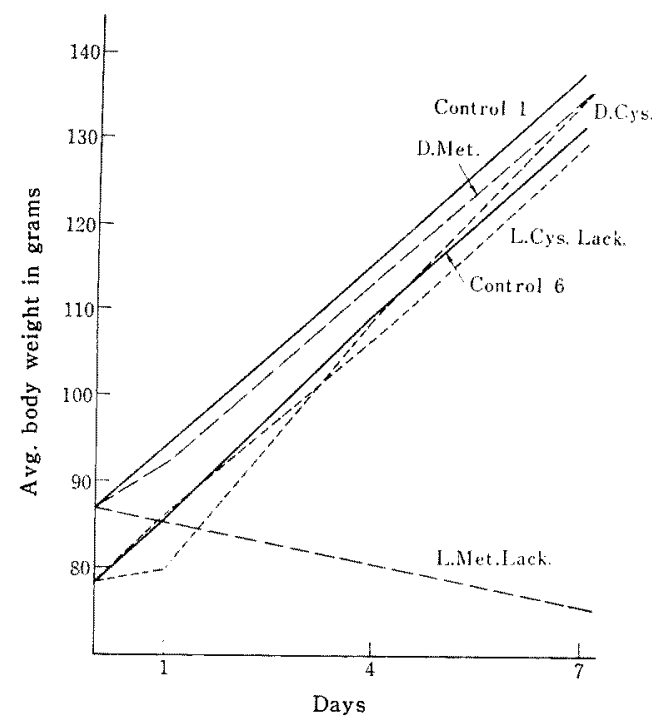

FJG. 1. Growtn Curves of Chicks Fed on DMethionine, D-Cystine and the Corresponding LIsomer Lacking Diet.

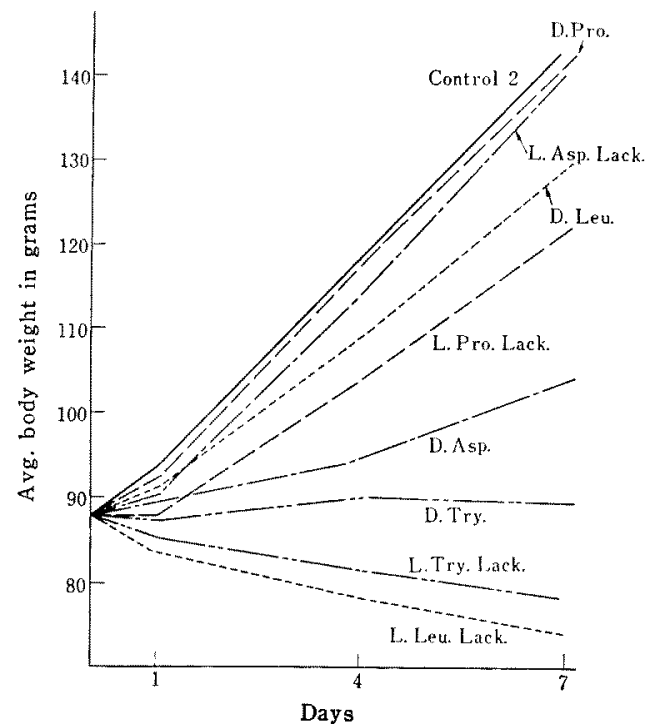

FIG. 2. Growth Curves of Chicks Fed on D-Leucine, D-Tryptophan, D-Proline, D-Aspartic Acid and the Corresponding L-Isomer Lacking Diet.
Thus 16 sorts of experimental diets lacking in a $\mathrm{L}$ amino acid and 16 sorts of experimental diets containing the corresponding $\mathrm{D}$-amino acid were prepared.

\section{RESULTS}

Methionine (Fig. 1. Table II). Chicks received $D$-methionine grew at a rate almost comparable to that on the group fed the control diet containing $\mathrm{L}$-methionine. Growth rate and nitrogen retention of chicks received D-methionine were slightly less than those of the control group but there was no statistical significance between both groups. The result shows D-methionine is almost equivalent to L-methionine in chick nutrition.

Phenylalanine (Fig. 3. Table III). Growth rate and nitrogen retention of chicks received D-phenylalanine were slightly less than those of the control group but there was no statistical significance between both groups. $D^{-}$ Phenylalanine would be almost equivalent to L-isomer in chick nutrition.

Proline (Fig. 2. Table III). Growth rate of chicks received the L-proline lacking diet was

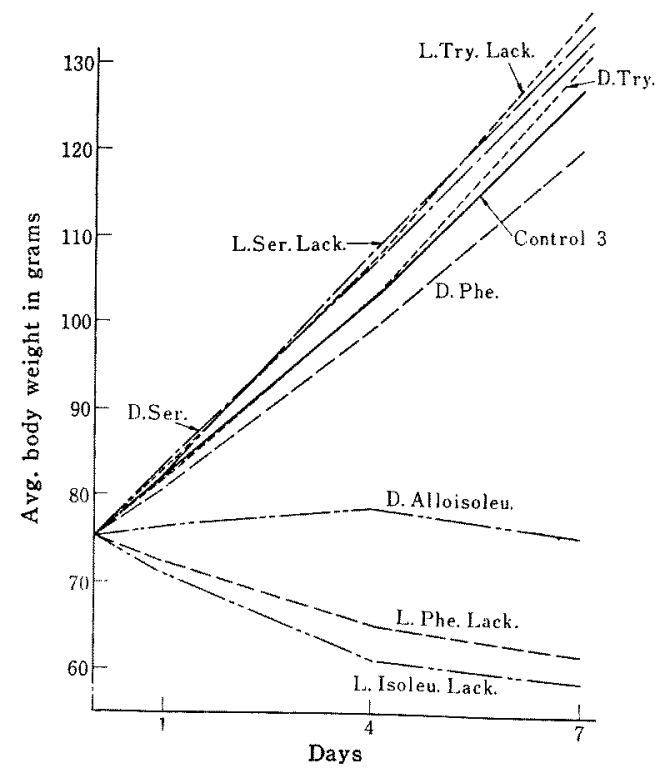

FIG. 3. Growth Curves of Chicks Fed on D-Phenylalanine, D-Isoleucine, D-Serine, $\mathrm{D}$-Tyrosine and the Corresponding L-Isomer Lacking Diet. 
about $70 \%$ of that of chicks received the control diet containing L-proline. There was statistical significance $(P=0.01)$ between both groups. Although Roy and Bird, ${ }^{81}$ Klain et al. ${ }^{91}$ and Green et al. ${ }^{101}$ reported the growth promotion of L-proline, in general, L-proline has been regarded as a non-essential amino acid in chick nutrition. The result presented here supports the conception of these authors. Chicks received D-proline showed the growth equal to the control group. At the same time the improvements of feed utilization, nitrogen retention and nitrogen efficiency by adding $D_{-}$ proline were observed. The nutritional value of D-proline would be almost equal to that of $\mathrm{L}$-proline in chick nutrition.

Leucine (Fig. 2, Table III). Growth rate of chicks received D-leucine was less than that of the control group. There was a statistical significance $(\mathrm{P}=0.05)$ between both groups. Feed utilization was slightly lower than that of the control group. D-Leucine would have slightly less nutritional value in comparison with L-leucine in chick nutrition.

Valine (Fig. 5, Table III). Apparently Lvaline in diet can be replaced by $\mathrm{D}$-valine for chick growth to some extent. But growth rate and feed utilization of chicks received $D^{-}$ valine were considerably inferior to those of the control group. D-Valine would have half nutritional value in comparison with L-isomer.

Tryptophan (Fig. 2, Table III). Chicks received the diet lacking in $\mathrm{L}$-tryptophan clearly decreased their body weight during the experimental period. Nitrogen retention of chicks received $D$-tryptophan was considerably improved in comparison with that of L-tryptophan lacking group; and chicks fed with D-tryptophan maintained their body weight during the experimental period. D-Tryptophan would be

8) D. N. Roy and H. R. Bird, Poultry Sci, 38, 192 (1959)

9) G. J. Klain, H. M. Scott and B. C. Johnson, ibid., 38, 489 (1959).

10) D. E. Greene, H. M. Scott and B. C. Johnson, ibid., 41, 116 (1962). utilized only to a limited extent by the chick.

Isoleucine (Fig. 3, Table III). Chicks fed on the diet lacking in L-isoleucine clearly decreased their body weight during the experimental period. Growth rate and nitrogen retention of chicks fed with the diet containing $\mathrm{D}$ alloisoleucine were considerably improved. DAlloisoleucine would be utilized only to a limited extent by the chick. Chicks fed on D-alloisoleucine showed wider standard deviation of the growth rate.

Histidine (Fig. 5, Table III). Chicks fed on the diet containing $\mathrm{D}$-histidine lost their weight. But weight loss of $\mathrm{D}$-histidine added group was a half of that of L-histidine lacking group and nitrogen retention of the former was better than that of the latter. Therefore, D-histidine appeared to be utilized very slightly in chick nutrition.

Lysine (Fig. 5, Table III), Threonine (Fig. 4, Table III), Arginine (Fig. 4, Table III). DIsomers of these amino acids showed no nutritional value in chick nutrition, because no

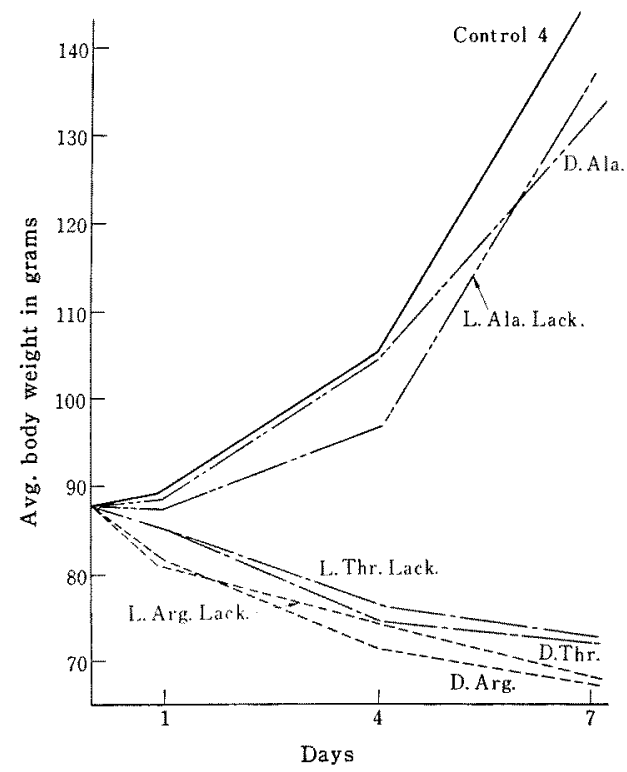

FIG. 4. Growth Gurves of Chicks Fed on DThreonine, D-Arginine, D-Alanine and the Corresponding L-Isomer Lacking Diet. 


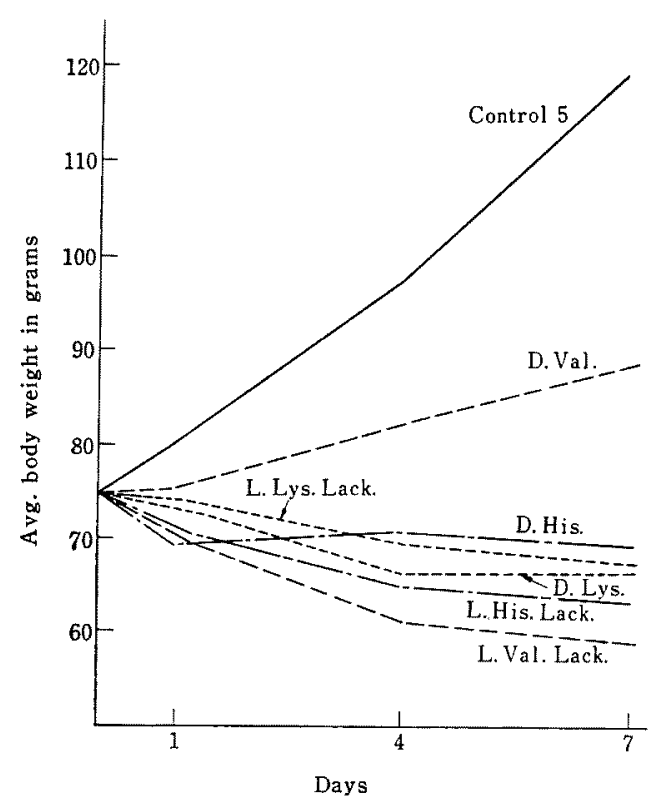

FIG. 5. Growth Curves of Chicks Fed on D-Valine, $\mathrm{D}$-Histidine, D-Lysine and the Corresponding $\mathrm{L}$ Isomer Lacking Diet.

differences observed between $\mathrm{D}$-amino acid added groups and the corresponding L-amino acid lacking groups, respectively. On the other hand, D-isomers of these amino acids appeared to have no growth retardation effect.

Tyrosine (Fig. 3, Table III), Serine (Fig. 3, Table III), Cystine (Fig. 1, Table III). These three L-amino acids were clearly non-essential for chick growth.

None of the groups of chicks fed on the diet containing one of those $\mathrm{D}$-isomers show any significant difference in their growth rate compared with that received the diet added or lacked in the corresponding L-amino acid. Since these three L-amino acids were nonessential in chick nutrition, it was impossible to distinguish whether these three $\mathrm{D}$-amino acids had the same nutritional values compared with those of L-amino acids or they had no nutritional value and were harmless to chick growth.

Alanine (Fig. 4, Table III). Although feed consumption of chicks fed with the diet containing $\mathrm{D}$-alanine was equal to that of chicks fed on the diet lacking in L-alanine, weight gain of the former was somewhat less than the latter. The tendency of the growth retardation was observed during the fourth day and the seventh day in group fed on $\mathrm{D}$-alanine.

The growth retardation by $\mathrm{D}$-alanine was reported by Adkins et al. ${ }^{111}$ with chick and by Brinbaum et al. ${ }^{12)}$ with rat. It is not proper to decide from this result that D-alanine has no growth retardation effect in chick nutrition.

Aspartic acid (Fig. 3, Table III). Weight gain and feed consumption of chicks fed with the diet containing $\mathrm{D}$-aspartic acid were clearly smaller than the control group or the corresponding L-amino acid lacking group. DAspartic acid has no nutritional value in chick nutrition and also has the retardation effect to chick growth.

The nutritional values of $\mathrm{D}$-amino acids in chick nutrition were tabulated below from the

Table IV. The Nutritional Value of D-AMiNo ACIDS BY THE CHICK

\begin{tabular}{|c|c|c|}
\hline Nutritional value & Essential & Non-essential \\
\hline $\begin{array}{l}\text { Equal or almost } \\
\text { equal to the } \\
\text { corresponding } \\
\text { L-isomers }\end{array}$ & $\begin{array}{l}\text { Methionine } \\
\text { Phenylalanine } \\
\text { Leucine } \\
\text { Proline }\end{array}$ & $\begin{array}{l}\text { Tyrosine* } \\
\text { Serine* } \\
\text { Cystine* }\end{array}$ \\
\hline $\begin{array}{l}\text { Slight growth } \\
\text { retardation }\end{array}$ & & Alanine \\
\hline $\begin{array}{l}\text { About half to the } \\
\text { corresponding } \\
\text { L-isomers }\end{array}$ & Valine & \\
\hline $\begin{array}{l}\text { Small nutritional } \\
\text { value }\end{array}$ & $\begin{array}{l}\text { Tryptophan } \\
\text { Histidine } \\
\text { Alloisoleucine }\end{array}$ & \\
\hline $\begin{array}{l}\text { No nutritional } \\
\text { value }\end{array}$ & $\begin{array}{l}\text { Lysine } \\
\text { Threonine } \\
\text { Arginine }\end{array}$ & \\
\hline $\begin{array}{l}\text { Growth } \\
\text { retardation }\end{array}$ & & Aspartic acid \\
\hline $\begin{array}{l}\text { * There is a } \\
\text { has no nut } \\
\text { chick grow }\end{array}$ & sibility that each & $\begin{array}{l}\text { D-amino acid } \\
\text { harmless for }\end{array}$ \\
\hline
\end{tabular}

11) J. S. Adkins, M. L. Sunde and A. E. Harper, Poultry Sci., 41, 1382 (1962).

12) S. M. Brinbaum, M. Winitz and J. P. Greenstein, Arch. Biochem. Biophys., 72, 428 (1957). 
results of this experiment. (Table IV).

\section{DISCUSSION}

Bauriedell, ${ }^{131}$ Fell et al. ${ }^{141}$ Leveille et al. ${ }^{15 !}$ and Grau and Almquist ${ }^{16)}$ reported that $D^{-}$ methionine had equal nutritional value of its $\mathrm{L}$-isomer. The result of this report is in agreement with these authors' observations.

Excellent nutritional value of D-phenylalanine shown in this experiment agrees with a report by Fell et al. ${ }^{14}$ and is appreciably better than that reported by Fisher et al. ${ }^{17}$ Snetsinger et al. ${ }^{5 /}$ reported that D-phenylalanine utilization by turkey poults varied, being an average of $28 \%$ as effective as its L-isomer when poults were fed on all L-essential amino acids mixture, but decreased to approximately half this amount when certain amino acids were furnished as DL-mixture.

Fell et al. ${ }^{141}$ reported that $\mathrm{D}$-leucine failed to support the chick growth when fed alone but when over $50 \%$ of the requirement was supplied in the $\mathrm{L}$-from, the $\mathrm{D}$-leucine was quite effective in supplying the remainder of the requirement. Since amino acid composition of their diet was not presented, it is difficult to compare their result with that of this report in detail but both results do not agree.

Fell et al. ${ }^{14)}$ reported that $\mathrm{D}$-valine slightly supported the growth of chicks. The result in this report agrees with their result. But Grau and Peterson ${ }^{(\mathrm{B})}$ reported that $\mathrm{D}$-valine was not utilized for chick growth. Leveille and Fisher ${ }^{191}$ reported that $\mathrm{D}$-valine appeared to be completely available for maintenance of nitrogen equilibrium in the adult rooster.

13) W. R. Bauriedel, Poultry Sci., 42, 214 (1963).

14) R. V. Fell, W. S. Wilkinson and A. B. Watts, ibid., 38, 1203 (1959).

15) G. A. Leveille, R. Shapiro and F. Fisher, $J$. Nutrition, 72, 8 (1960).

16) C. R. Grau and H. J. Almquist, ibid, 26 , 431 (1943).

17) H. Fisher, D. Johnson and G. A. Leveille, ibid., 62, 349 (1957).

18) C. R. Grau and D. W. Peterson, J. Nutrition, 32, $181(1946)$.

19) G. A. Leveille and H. Fisher, ibid., 70, 135 (1960).
Wilkening and Schveigert ${ }^{201}$ reported that D-tryptophan was utilized to an extent of 17 to 40 percent by the chick. Grau and Almquist ${ }^{21}$ showed DL-tryptophan to be only half as effective as L-tryptophan in promoting growth and efficient food utilization in the chick. Morrison et al. $^{22)}$ suggested that Dtryptophan could promote chick growth in comparable extent to that obtained by the use of L-isomer. The nutritional value of $\mathrm{D}$ tryptophan shown in this report is considerably less in comparison with the Morrison's result. Fell et al. ${ }^{14}$ reported that $D^{-t r y p t o p h a n ~ f a i l e d ~}$ to support chick growth.

No nutritional value of $\mathrm{D}$-isoleucine by the chick was reported by Grau and Peterson ${ }^{181}$ and by Fell et al. ${ }^{14 !}$ Leveille and Fisher ${ }^{191}$ suggested that $\mathrm{D}$-isoleucine was unavailable for the maintenance of nitrogen equilibrium in the adult rooster. The result in this report shows that $\mathrm{D}$-alloisoleucine has small nutritional value.

Fell et al. ${ }^{141}$ observed that a racemic mixture depressed the growth promoting ability of Llysine. Krazter ${ }^{23}$ reported that turkey poults were unable to use D-lysine for growth and levels of D-lysine up to $1 \%$ did not depress growth, whereas $2 \%$ caused decreased growth. $\mathrm{Grau}^{24}$ found that ou-threonine was half as active as L-threonine in chick growth. Unavailability of $\mathrm{D}$-threonine for the maintenance of nitrogen equilibrium in the adult rooster was reported by Leveille and Fisher. ${ }^{19 /}$ These results agree with the observation shown in this report that $\mathrm{D}$-isomers of these two amino acids have no nutritional value.

Most of the experimental works have reported unsatisfactory chick growth on ad libitum feeding of diet containing crystalline amino

20) M. C. Wilkening and B. S. Schveigert, J. Biol. Chem., 171, 209 (1947).

21) C. R. Grau and H. J. Almquist, J. Nutrition, $\mathbf{2 8}, 263(1944)$.

22) W. D. Morrison, T. S. Hamilton and H. M. Scott, ibid., 60, 47 (1956).

23) F. H. Krazter, ibid., 41, 153 (1950).

$24)$ C. R. Grau, ibid., 37, 105 (1949). 
acids as a sole source of nitrogen. Dean and $\mathrm{Scott}^{25 !}$ reported satisfactory chick growth compared with the practical diet.

The control diet used in this experiment showed $80 \%$ of weight gain on the practical diet. (Crude protein content 21.5\%) (Table III). The standard deviation in growth rate of chicks fed on the control diet was greater than that of chicks with the practical diet. Crude protein content of the control diet was $21 \%$ and the composition of the amino acids in the control diet was in the same proportion as found in the whole egg protein ${ }^{26)}$ which is believed to have the best nutritional value among the intact proteins. Therefore, the results obtained here will be able to apply to the case in practical feed as far as amino acid composition is concerned.

Because of the difficulties to prepare the large amount of all amino acids, the feeding experiments of this type have been run in short period (for 7 10 days) by most of workers. So it is difficult to find out the effect of amino acid after a long run feeding from the results of these experiments. This experiment has the same defect.

The effect of continued administration of D-amino acid for animals is uncertain. Many

25) W. F. Dean and H. M. Scott, Poultry Sci., 44, 803 (1965).

26) R.J. Block, "Amino Acid Handbook", Charles C. Thomas Publish, 1956, p. 341 . biochemical experiments are necessary to elucidate the effect of D-amino acid for animals. For example: checking the matabolic fate of ingested $D$-amino acid by tracer dose of $\mathrm{C}^{14} \cdot \mathrm{N}^{15}$ $\mathrm{D}$-amino acid, examinating the variation of $\mathrm{D}$ amino acid oxidase activity in liver and kidney under D-amino acid administration or the influence of ingested D-amino acid for the glands of internal secretion.

Nowadays, the pathway of D-amino acid utilization is regarded as follows: D-amino acid absorbed is converted to corresponding $\alpha$-keto acid by $D$-amino acid oxidation in liver or kidney. Then $\alpha$-keto acid produced is converted to L-amino acid by transamination.

There are wide differences among the nutritional values of $\mathrm{D}$-amino acids as shown in Table IV. Further experiments will be needed to give the metabolic explanation for the differences of the nutritional values of $\mathrm{D}$-amino acids.

A table on the nutritional values of $16 \mathrm{D}$ amino acids in chick growth was presented from the results of experiments under uniform condition to give a general information on the nutritional value of D-amino acids and their use in feed industry.

Acknowledgement We wish to thank Dr. Tetsuo Hino, Dr. Takekazu Akashi and Mr. Koichi Hayashi for many technical help in the preparation of $\mathrm{D}$-amino acids. 